\title{
Hydrocephalus and diffuse choroid plexus hyperplasia in primary ciliary dyskinesia-related MCIDAS mutation
}

Evie Alexandra Robson, MBBS, MRCPCH, MSc, Luke Dixon, MBBS, BSc, FRCP, Liam Causon, William Dawes, BSc, FRCS(SN), PhD, Massimo Benenati, MD, Mahmoud Fassad, PhD, Robert Anthony Hirst, BSc, PhD, Priti Kenia, MBBS, MD, MRCPCH, MD, Eduardo Fernandez Moya, LMS, MRCPCH, Mitali Patel, BSc, MSc, Daniel Peckham, MBBS, DM, FRCP, Andrew Rutman, CBiol, MRSB, Hannah M. Mitchison, BSc, PhD, Kshitij Mankad, MRCP, FRCP,* and Christopher O'Callaghan, BMed Sci, BMBS, FRCPCH, PhD, DM*

Neurol Genet 2020;6:e482. doi:10.1212/NXG.0000000000000482

\section{Abstract}

\section{Objective}

To report a neuroradiologic phenotype associated with reduced generation of multiple motile cilia (RGMC) and mutations in the multicilin gene. We hypothesize that the observed phenotype may reflect the emerging role that ependymal cilia play in regulating CSF production.

\section{Method}

Clinical and radiologic records were retrospectively reviewed for 7 consecutive patients diagnosed by the Leicester UK national primary ciliary dyskinesia (PCD) diagnostic laboratory.

\section{Results}

On MRI scanning, all patients demonstrated hydrocephalus, choroid plexus hyperplasia $(\mathrm{CPH})$, and arachnoid cysts. No patient had any sign of neurologic deficit. All patients had significant lung disease.

\section{Conclusions}

We conclude that there is a high incidence of hydrocephalus, arachnoid cysts, and $\mathrm{CPH}$ in MCIDAS-associated RGMC. In all cases, the observed hydrocephalus seems arrested in childhood without progression or adverse neurologic sequelae. Our new observation of $\mathrm{CPH}$, which is associated with CSF overproduction, is the first macroscopic evidence that ependymal cilia may be involved in the regulation of CSF production and flow. We suggest that brain imaging should be performed in all cases of RGMC and that a diagnosis of PCD or RGMC be strongly considered in patients with unexplained hydrocephalus and a lifelong "wet"-sounding cough.

\author{
Correspondence \\ Dr. Robson \\ evie.robson@nhs.net
}

From the North of England Paediatric Primary Ciliary Dyskinesia Management Service (E.A.R., E.F.M., D.P.), Leeds General Infirmary, Great George Street, UK; Department of Radiology (L.D., W.D., M.B., K.M.), Great Ormond Street Hospital for Children, London, UK; Centre for PCD Diagnosis and Research (R.A.H., A.R., C.O.), Department of Respiratory Sciences, University of Leicester, Robert Kilpatrick Clinical Sciences Building, Leicester Royal Infirmary, UK; Birmingham Women's and Children's Hospital (L.C., P.K.), Steelhouse Lane, Birmingham, UK; Genetics and Genomic Medicine Programme (M.F., H.M.), University College London, UCL Great Ormond Street Institute of Child Health, London, UK; Department of Human Genetics (M.F.), Medical Research Institute, Alexandria University, El- Hadra, Alexandria, Egypt; The North of England Adult Primary Ciliary Dyskinesia Management service, St James's University Hospital, Leeds, UK; and UCL Great Ormond Street Institute of Child Health \& NIHR GOSH BRC (C.O.), London, UK. 


\section{Glossary}

CCNO = Cyclin O; $\mathbf{C P H}=$ choroid plexus hyperplasia; $\mathbf{M C I D A S}=$ multiciliate differentiation and DNA synthesis associated cell cycle protein; $\mathbf{P C D}$ = primary ciliary dyskinesia; $\mathbf{R G M C ~ = ~ r e d u c e d ~ g e n e r a t i o n ~ o f ~ m u l t i p l e ~ m o t i l e ~ c i l i a . ~}$

Primary ciliary dyskinesia (PCD) is a rare heterogenous group of disorders causing abnormal motile ciliary function, with defective mucociliary clearance leading to lung and sinonasal disease. Hydrocephalus is common in small animals with PCD and is believed to be due to defective ependymal cilia, which in health, beat at approximately $40 \mathrm{~Hz}$ moving CSF. ${ }^{1}$ Hydrocephalus is, however, rarely seen in human PCD. ${ }^{2,3}$

Reduced generation of multiple motile cilia (RGMC) is recognized as a severe PCD phenotype which is associated with almost complete loss of motile cilia. ${ }^{4}$ Mutations in 3 genes have been identified as disease causing. Recessively, inherited RGMCcausing mutations are reported in MCIDAS encoding multicillin, an upstream regulator of human multiciliated cell differentiation, ${ }^{4}$ and in $C \mathrm{CNO}$ encoding cyclin $\mathrm{O}$, which acts downstream on mother centriole generation and migration. ${ }^{5}$ More recently, dominantly inherited RGMC-causing mutations were reported in FOXJ1 encoding the FOXJ1 transcription factor that also regulates multiciliogenesis but in a distinct pathway that is downstream of multiciliate differentiation and DNA synthesis associated cell cycle protein (MCIDAS) and works in parallel to Cyclin O (CCNO). ${ }^{10}$ Although hydrocephalus associated with RGMC has been reported, details of intracranial imaging are limited. ${ }^{2-9}$ Here, we report hydrocephalus and the novel finding of diffuse choroid plexus hyperplasia $(\mathrm{CPH})$.

\section{Methods}

Retrospective cohort study for 7 consecutive patients diagnosed with MCIDAS by the Leicester UK national PCD diagnostic laboratory. Sanger DNA sequencing for individuals A and B was previously reported ${ }^{4}$ and next-generation targeted gene panel sequencing for C-E was performed as described previously. ${ }^{20}$

\section{Standard protocol approvals, registrations, and patient consents}

Written informed consent was gained for data publication, along with Research Ethics Committee approval (REC ref: $18 / \mathrm{LO} / 2085)$ for retrospective data collection for patients referred to the PCD national diagnostics service to allow evaluation and understanding of ciliary defects.

\section{Data availability}

Anonymized data and detailed methodology not published within this article may be shared by request to the senior author.

\section{Cases}

Patients A and B are term monozygotic twins, with South Asian first cousin parents. On day 7 of life, Twin B developed seizures that settled. Cranial ultrasound scan was reported to be within normal limits, although mild dilatation of posterior horns of both lateral ventricles were noted.

Twin A required bilateral lung transplantation aged 16 years. An MRI scan investigating transient encephalopathy after transplant demonstrated hydrocephalus and CPH. Subsequent MRI of Twin $B$ showed hydrocephalus and CPH (figure 1 and table). Neither sibling had neurologic symptoms or developmental delay.

Genetic testing revealed a biallelic homozygous nonsense mutation in MCIDAS (c.441C > A; p.Cys $147^{*}$ ), as previously reported. ${ }^{4}$ Both siblings carried the same homozygous mutation, and segregation analysis showed parents to be carriers (see figure 2 for Sanger sequencing).

Patients C, D, and E are siblings born to Asian first cousin parents. Genetic testing revealed each child had a novel biallelic homozygous nonsense mutation in MCIDAS, c. $1093 \mathrm{C}>\mathrm{T}, \mathrm{p} . \mathrm{Gln} 365^{*}$ (figure 2). MRI scans showed that all 3 siblings had hydrocephalus and $\mathrm{CPH}$ (figure 1 and table). None of the siblings had neurologic signs or developmental delay.

Siblings $\mathrm{F}$ and $\mathrm{G}$ were born at term to first cousin parents who are paternal and maternal first cousins of siblings $\mathrm{C}, \mathrm{D}$, and $\mathrm{E}$.

Sibling F was diagnosed antenatally with communicating hydrocephalus, whereas sibling $G$ had increasing head circumference noted in infancy. Sibling G's first cranial ultrasound scan showed $\mathrm{CPH}$ with bitemporal arachnoid cysts. Follow-up ultrasound showed persistent $\mathrm{CPH}$ and increased CSF spaces, with increased lateral and $3^{\text {rd }}$ ventricle dilation. Head circumference growth normalized. Subsequent MRI head scans of both siblings demonstrated hydrocephalus and $\mathrm{CPH}$ (figure 1 and table). Neither sibling had neurologic signs or developmental delay.

Genetic testing showed that both had MCIDAS biallelic homozygous nonsense mutation, c.1093C > T, p.Glu365*, identical to their first cousins, siblings $\mathrm{C}, \mathrm{D}$, and $\mathrm{E}$ (figure 2).

\section{Discussion}

Our series of MCIDAS mutations confirms a strong association with hydrocephalus ${ }^{5-8}$ and describes an additional finding of $\mathrm{CPH}$. This differs from RGMC because of biallelic CCNO mutations, where only $10 \%$ demonstrated hydrocephalus. All children had accelerated lung disease and normal situs arrangement, indicating no functional role for MCIDAS in left-right determination consistent with the previous reports. ${ }^{4}$ 


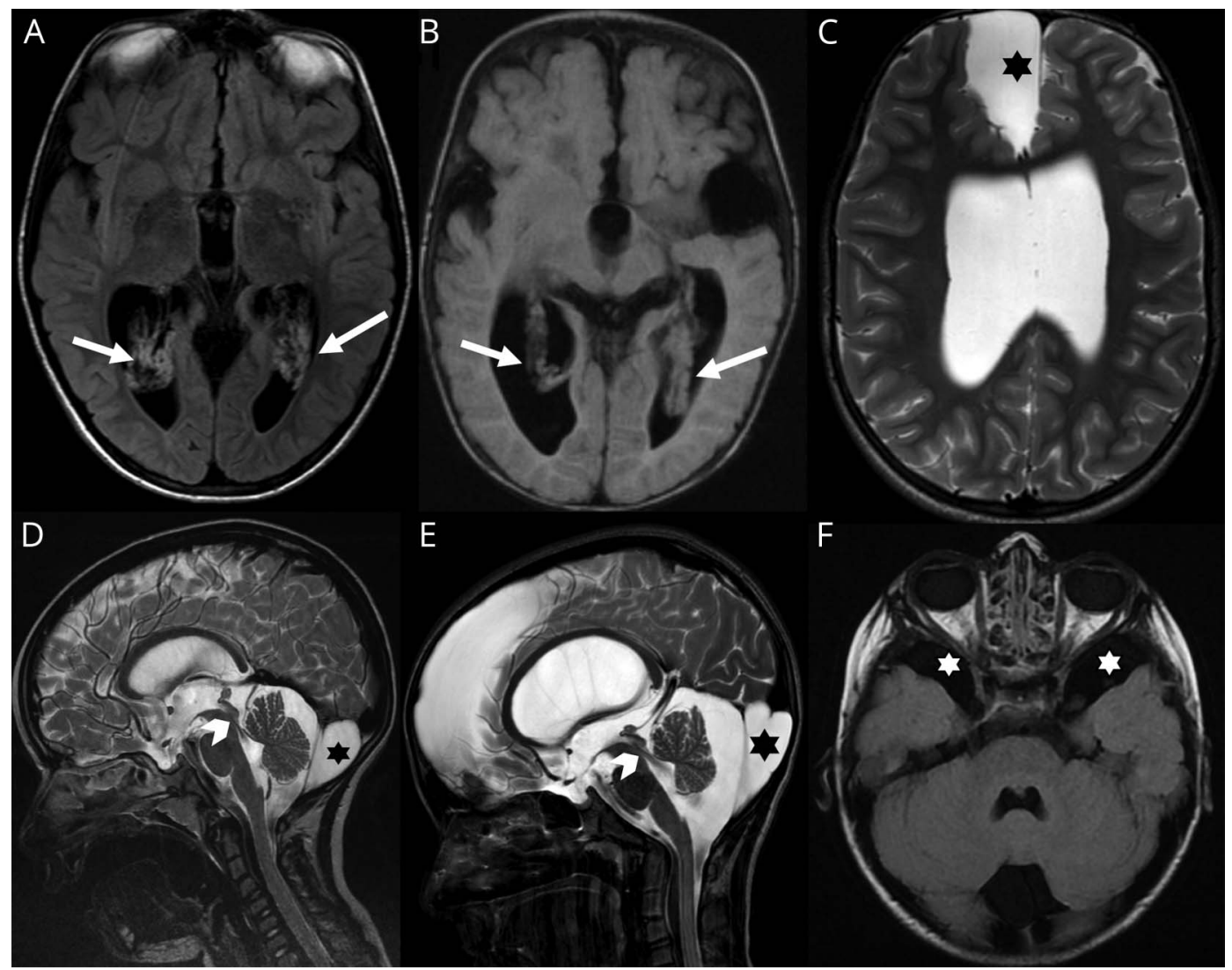

Images A, C, and E correspond with patient D; D and F, with patient G; and B, with patient F. Note (A) [axial FLAIR] and (B) [axial T1-WI] on different patients showing choroid plexus hyperplasia (arrows). High-resolution sagittal T2-WI (D, E) confirming CSF flow through the aqueduct of Sylvius (arrowheads) and large retro cerebellar arachnoid cyst in both cases (stars). Further arachnoid cysts were noted in other locations as shown in C (axial T2-WI) and F (axial FLAIR) within the anterior and middle cranial fossae respectively (stars).

The mechanisms causing hydrocephalus in RGMC remain unclear. It is suggested that CSF flow generated by rapidly beating ependymal cilia helps maintain patency of narrow sites of CSF passage in early postnatal development. ${ }^{2}$ This is supported by the observation of stenosis of the cerebral aqueduct and other ventricular foramina in patients carrying mutations in FOXJ1, a transcription factor important for ciliogenesis. ${ }^{10}$

Although primary aqueduct stenosis can cause hydrocephalus, in some cases, it is believed to occur as a secondary phenomenon, resulting from hydrocephalus of different etiologies. Similarly, PCD mice with largely static ependymal cilia $(C c d c 151$ knockout) developed hydrocephalus with patent aqueducts visible by micro-CT. ${ }^{11,12}$ None of our patients with MCIDAS had CSF pathway stenosis. This phenotype of hydrocephalus with open cerebral aqueduct suggests a different cause of hydrocephalus in RGMC, where ventricles are presumed to lack cilia compared with that of classic PCD where the cilia are present but dysmotile.

Ependymal cilia are believed to play important roles in CSF homeostasis, both through paracrine modulation ${ }^{13}$ and in host defense, clearing debris and cells from ependymal surfaces. ${ }^{14}$ The CSF microenvironment has been shown to affect choroid plexus
CSF production, for example, in a rat model of intraventricular hemorrhage. Karimy et al. ${ }^{15}$ demonstrated a 3-fold increase in CSF production secondary to toll-like receptor 4 (TLR4) activation within the choroid plexus epithelium. As such, changes in the CSF microenvironment secondary to loss of motile cilia may promote increased choroid plexus production of CSF.

An alternative explanation for the observed phenotype is that the absence of cilia affects ion transport across the choroid plexus epithelium. ${ }^{16}$ This theory is supported by mouse models with ependymal ciliogenesis defects, for example, IFT88-deficient $T g 737^{o r p k}$ mice defective for ependymal cilia assembly have CSF that shows an abnormal accumulation of intracellular cyclic adenosine monophosphat and aberrant regulation of intracellular $\mathrm{pH}$ and ion transport, a finding associated with upregulated CSF chloride transport and increased CSF production sufficient to cause hydrocephalus. ${ }^{16}$ Accumulation of cyclic adenosine monophosphat and increased transcytosis was also observed in a study using chloral hydrate to deciliate swine choroid plexus. ${ }^{17,18}$ In other mouse models affecting ependymal ciliogenesis, for example, Kif3a mutants deficient for a kinesin motor protein required for ciliary protein transport, hydrocephalus was observed in the neonatal period before the development of mature motile cilia. ${ }^{16,19}$ Based on 
Table Summary of disease characteristics

\begin{tabular}{|c|c|c|c|c|c|c|c|}
\hline & \multicolumn{7}{|c|}{ Sibling set } \\
\hline & \multicolumn{2}{|l|}{1} & \multicolumn{3}{|l|}{2} & \multicolumn{2}{|l|}{3} \\
\hline & A & B & C & D & E & $\mathbf{F}$ & G \\
\hline Age at diagnosis (y) & 3 & 3 & 1 & $1 \mathrm{~m}$ & $3 \mathrm{~m}$ & 6 & 5 \\
\hline nNO (ppb) & - & 36 & 5,7 & 30 & 10 & 12 & 9 \\
\hline Number of ciliary brushing samples & 4 & 2 & 2 & 4 & 3 & 2 & 2 \\
\hline No cilia seen on high-speed video microscopy & Yes & Yes & Yes & Yes & Yes & Yes & Yes \\
\hline No cilia seen on multiple airway biopsies or culture & Yes & Yes & Yes & Yes & Yes & Yes & Yes \\
\hline Neonatal symptoms present & Yes & Yes & Yes & Yes & Yes & Yes & Yes \\
\hline Accelerated respiratory disease & Yes & Yes & Yes & Yes & Yes & Yes & Yes \\
\hline Situs status & Solitus & Solitus & Solitus & Solitus & Solitus & Solitus & Solitus \\
\hline Hydrocephalus confirmed & Yes & Yes & Yes & Yes & Yes & Yes & Yes \\
\hline Diffuse choroid plexus hyperplasia & Yes & Yes & Yes & Yes & Yes & Yes & Yes \\
\hline Arachnoid cysts & Yes & Yes & Yes & Yes & Yes & Yes & Yes \\
\hline Aquaduct patency & Patent & Patent & Patent & Patent & Patent & Patent & Patent \\
\hline Age at MRI (y) & 16 & 16 & 10 & 9 & 4 & $5 \mathrm{~m}$ & 5 \\
\hline
\end{tabular}

this observation, it was suggested that hydrocephalus in these ependymal cilia mutant mice was secondary to choroid plexus CSF overproduction. ${ }^{16,19}$

In our study, the observation of diffuse $\mathrm{CPH}$ in patients with MCIDAS mutation is, to our knowledge, the first structural, macroscopic evidence that supports the theory that hydrocephalus in certain types of PCD is secondary to $\mathrm{CSF}$ overproduction. $\mathrm{CPH}$ is rare and is characterized by an enlarged morphologically normal choroid plexus, which is known to cause CSF overproduction and hydrocephalus. The mechanism by which MCIDAS and other proteins involved in ependymal ciliogenesis potentially cause $\mathrm{CPH}$ is possibly related to growing evidence that choroid plexus cilia

Figure 2 Familial segregation of MCIDAS mutations detected in reduced generation of multiple motile cilia families

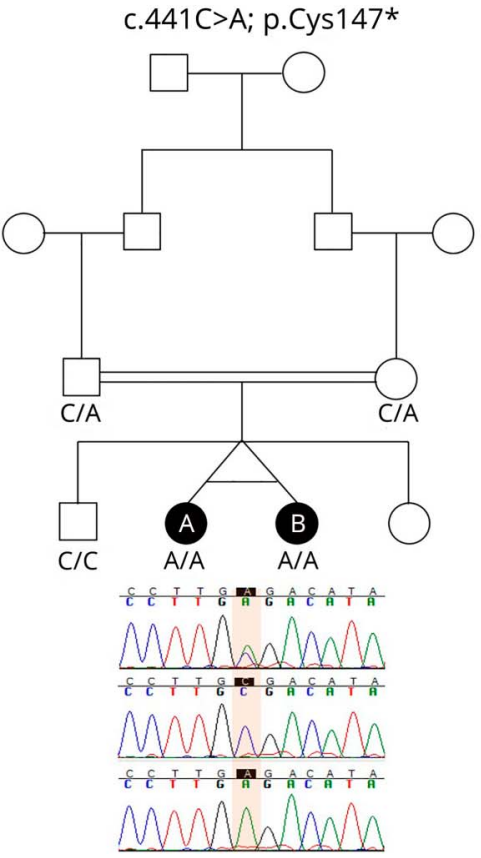

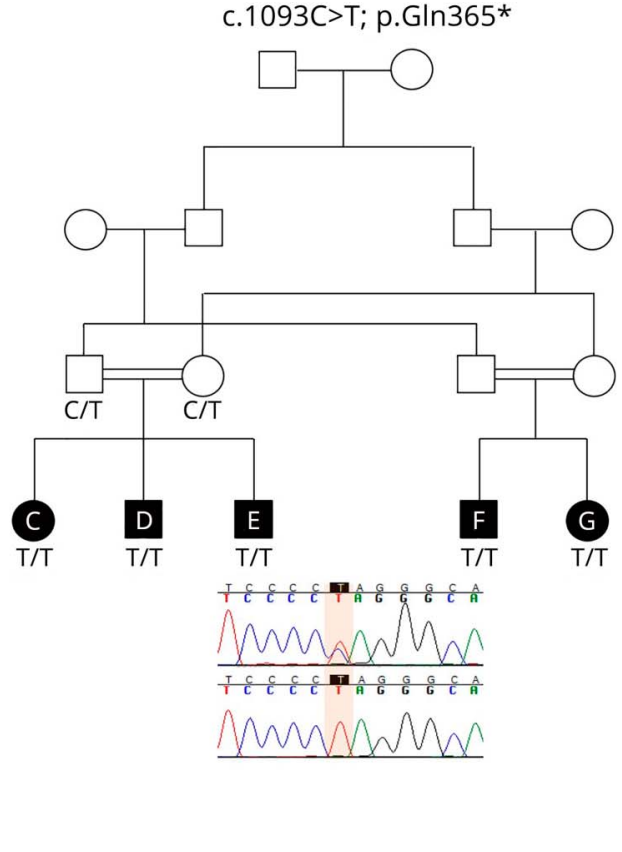

Mutations were identified by next-generation gene panel sequencing of family members. The sequences of a carrier parent (top) and affected child (bottom) are shown for pedigree of C, D, E, F and $\mathrm{G}$ with the mutation highlighted in the box. Sequences for $A$ and $B$ were reported previously. ${ }^{4,20}$ 
may regulate CSF production via effects on choroid plexus ependymal cells.

Our second observation of arachnoid cysts in patients with MCIDAS mutation has not been previously reported. Cysts are possibly secondary to tears in the arachnoid from abnormal CSF flow or alternatively from adhesions after impaired clearance of CSF debris because of absent motile cilia. Despite abnormalities on neuroimaging, none of the MCIDAS-deficient patients had neurologic findings or developmental delay. This is likely related to relatively early development of hydrocephalus, when the brain is structurally compliant and able to compensate to high CSF pressures.

\section{Conclusion}

The observation of $\mathrm{CPH}$ in RGMC secondary to MCIDAS mutations provides further evidence that ependymal cilia are potentially involved in regulation of CSF production in addition to CSF flow. Our results suggest the process is not progressive but rather represents an arrested/stable state. This is clinically important because benefits of ventriculoperitoneal shunting in this patient group need to be carefully considered. We recommend that if unexplained hydrocephalus is found in patients with lifelong wet-sounding cough, referral for diagnostic testing for PCD and RGMC should be strongly considered. Similarly, cranial imaging is indicated in RGMC.

\section{Study funding}

This research article is supported by the NIHR GOSH BRC. The views expressed are those of the author(s) and not necessarily those of the NHS, the NIHR, or the Department of Health.

\section{Disclosure}

E.A. Robson, L. Dixon, L. Causon, W. Dawes, M. Benenati, M. Fassad, R. A. Hirst, P. Kenia, E.F. Moya, M. Patel, D. Peckham, A. Rutman, H. Mitchison, K. Mankad, and C. O'Callaghan report no disclosures relevant to the manuscript. Go to Neurology.org/NG for full disclosures.

\section{Publication history}

Received by Neurology: Genetics April 11, 2020. Accepted in final form June 9, 2020.

\section{Appendix Authors}

\begin{tabular}{|c|c|c|}
\hline Name & Location & Contribution \\
\hline $\begin{array}{l}\text { Evie Alexandra } \\
\text { Robson, MBBS, } \\
\text { MRCPCH, MSc }\end{array}$ & $\begin{array}{l}\text { Northern PCD } \\
\text { management centre, } \\
\text { Leeds, UK }\end{array}$ & $\begin{array}{l}\text { Drafted and finalized } \\
\text { the manuscript for } \\
\text { intellectual content and } \\
\text { major role in } \\
\text { acquisition of data }\end{array}$ \\
\hline $\begin{array}{l}\text { Christopher } \\
\text { O'Callaghan, BMed } \\
\text { Sci, BMBS, FRCPCH, } \\
\text { PhD, DM }\end{array}$ & $\begin{array}{l}\text { University of Leicester, } \\
\text { Leicester Royal } \\
\text { Infirmary, Leicester, UK } \\
\text { UCL Great Ormond } \\
\text { Street Institute of Child } \\
\text { Health, London, UK }\end{array}$ & $\begin{array}{l}\text { Design and } \\
\text { conceptualized the } \\
\text { study, major role in the } \\
\text { acquisition of data, and } \\
\text { revised the manuscript } \\
\text { for intellectual content }\end{array}$ \\
\hline
\end{tabular}

Appendix (continued)

\begin{tabular}{|c|c|c|}
\hline Name & Location & Contribution \\
\hline $\begin{array}{l}\text { Kshitij Mankad, } \\
\text { MRCP, FRCP }\end{array}$ & $\begin{array}{l}\text { Great Ormond Street } \\
\text { Hospital for Children, } \\
\text { London, UK }\end{array}$ & $\begin{array}{l}\text { Analyzed the data, } \\
\text { interpreted the data, } \\
\text { and revised the } \\
\text { manuscript for } \\
\text { intellectual content }\end{array}$ \\
\hline $\begin{array}{l}\text { William Dawes, } \\
\text { BSc, FRCS(SN), PhD }\end{array}$ & $\begin{array}{l}\text { Great Ormond Street } \\
\text { Hospital for Children, } \\
\text { London, UK }\end{array}$ & $\begin{array}{l}\text { Interpreted the data } \\
\text { and revised the } \\
\text { manuscript for } \\
\text { intellectual content }\end{array}$ \\
\hline $\begin{array}{l}\text { Luke Dixon, MBBS, } \\
\text { BSc, FRCP }\end{array}$ & $\begin{array}{l}\text { Great Ormond Street } \\
\text { Hospital for Children, } \\
\text { London, UK }\end{array}$ & $\begin{array}{l}\text { Interpreted the data } \\
\text { and revised the } \\
\text { manuscript for } \\
\text { intellectual content }\end{array}$ \\
\hline $\begin{array}{l}\text { Robert Anthony } \\
\text { Hirst, BSc, PhD }\end{array}$ & $\begin{array}{l}\text { University of Leicester, } \\
\text { Robert Leicester Royal } \\
\text { Infirmary, Leicester, UK }\end{array}$ & $\begin{array}{l}\text { Interpreted the data } \\
\text { and revised the } \\
\text { manuscript for } \\
\text { intellectual content }\end{array}$ \\
\hline $\begin{array}{l}\text { Andrew Rutman, } \\
\text { CBiol, MRSB }\end{array}$ & $\begin{array}{l}\text { University of Leicester, } \\
\text { Leicester Royal } \\
\text { Infirmary, Leicester, UK }\end{array}$ & $\begin{array}{l}\text { Interpreted and } \\
\text { analyzed the data }\end{array}$ \\
\hline $\begin{array}{l}\text { Hannah M. } \\
\text { Mitchison, BSc, } \\
\text { PhD }\end{array}$ & $\begin{array}{l}\text { UCL Great Ormond } \\
\text { Street Institute of Child } \\
\text { Health, London, UK }\end{array}$ & $\begin{array}{l}\text { Analyzed the data, } \\
\text { interpreted the data, } \\
\text { and revised the } \\
\text { manuscript for } \\
\text { intellectual content }\end{array}$ \\
\hline $\begin{array}{l}\text { Daniel Peckham, } \\
\text { MBBS, DM, FRCP }\end{array}$ & $\begin{array}{l}\text { Northern PCD } \\
\text { management centre, } \\
\text { Leeds, UK }\end{array}$ & $\begin{array}{l}\text { Interpreted the data } \\
\text { and revised the } \\
\text { manuscript for } \\
\text { intellectual content }\end{array}$ \\
\hline $\begin{array}{l}\text { Massimo Benenati, } \\
\text { MD }\end{array}$ & $\begin{array}{l}\text { Great Ormond Street } \\
\text { Hospital for Children, } \\
\text { London, UK }\end{array}$ & $\begin{array}{l}\text { Interpreted and } \\
\text { analyzed the data and } \\
\text { revised the manuscript } \\
\text { for intellectual content }\end{array}$ \\
\hline $\begin{array}{l}\text { Priti Kenia, MBBS, } \\
\text { MD, MRCPCH, MD }\end{array}$ & $\begin{array}{l}\text { Birmingham Women's } \\
\text { and Children's } \\
\text { Hospital, Birmingham, } \\
\text { UK }\end{array}$ & $\begin{array}{l}\text { Interpreted the data } \\
\text { and revised the } \\
\text { manuscript for } \\
\text { intellectual content }\end{array}$ \\
\hline $\begin{array}{l}\text { Eduardo } \\
\text { Fernandez Moya, } \\
\text { LMS, MRCPCH }\end{array}$ & $\begin{array}{l}\text { Northern PCD } \\
\text { management centre, } \\
\text { Leeds, UK }\end{array}$ & $\begin{array}{l}\text { Interpreted the data } \\
\text { and revised the } \\
\text { manuscript for } \\
\text { intellectual content }\end{array}$ \\
\hline Liam Causon & $\begin{array}{l}\text { Birmingham Women's } \\
\text { and Children's } \\
\text { Hospital, Birmingham } \\
\text { UK }\end{array}$ & $\begin{array}{l}\text { Major role in } \\
\text { acquisition of data }\end{array}$ \\
\hline $\begin{array}{l}\text { Mahmoud Fassad, } \\
\text { PhD }\end{array}$ & $\begin{array}{l}\text { UCL Great Ormond } \\
\text { Street institute of Child } \\
\text { Health, London, UK }\end{array}$ & $\begin{array}{l}\text { Interpreted and } \\
\text { analyzed the data }\end{array}$ \\
\hline $\begin{array}{l}\text { Mitali Patel, BSc, } \\
\text { MSc }\end{array}$ & $\begin{array}{l}\text { UCL Great Ormond } \\
\text { Street institute of Child } \\
\text { Health, London, UK }\end{array}$ & $\begin{array}{l}\text { Interpreted and } \\
\text { analyzed the data }\end{array}$ \\
\hline
\end{tabular}

\section{References}

1. Chilvers MA, O'Callaghan C. Analysis of ciliary beat pattern and beat frequency using digital high speed imaging: comparison with the photomultiplier and photodiode methods. Thorax 2000;55:314-317.

2. Ibanez-Tallon I, Pagenstecher A, Fliegauf M, et al. Dysfunction of axonemal dynein heavy chain Mdnah5 inhibits ependymal flow and reveals a novel mechanism for hydrocephalus formation. Hum Mol Genet 2004;13:2133-2141.

3. Vieira JP, Lopes P, Silva R, Primary ciliary dyskinesia and hydrocephalus with aqueductal stenosis. J Child Neurol 2012;27:938-941. 
4. Boon M, Wallmeier J, Ma L, et al. MCIDAS mutations result in a mucociliary clearance disorder with reduced generation of multiple motile cilia. Nat Commun 2014;5:4418.

5. Wallmeier J, Al-Mutairi DA, Chen CT, et al. Mutations in CCNO result in congenital mucociliary clearance disorder with reduced generation of multiple motile cilia. Nat Genet 2014;46:646-651.

6. Berlucchi M, de Santi MM, Bertoni E, Spinelli E, Timpano S, Padoan R. Ciliary aplasia associated with hydrocephalus: an extremely rare occurrence. Eur Arch Otorhinolaryngol 2012;269:2295-2299.

7. De Santi MM, Magni A, Valletta EA, Gardi C, Lungarella G. Hydrocephalus, bronchiectasis, and ciliary aplasia. Arch Dis Child 1990;65:543-544.

8. Amirav I, Wallmeier J, Loges NT, et al. Systematic analysis of CCNO variants in a defined population: implications for clinical phenotype and differential diagnosis. Hum Mutat 2016;37:396-405.

9. Afzelius BA. A human syndrome caused by immotile cilia. Science 1976;193:317-319.

10. Wallmeier J, Frank D, Shoemark A, et al. De novo mutations in FOXJ1 result in a motile ciliopathy with hydrocephalus and randomization of left/right body asymmetry. Am J Hum Genet 2019;105:1030-1039.

11. Chiani F, Orsini T, Gambadoro A, et al, Functional loss of Ccdc1 51 leads to hydrocephalus in a mouse model of primary ciliary dyskinesia. Dis Model Mech 2019;12: dmm038489.
12. Hjeij R, Onoufriadis A, Watson CM, et al. CCDC151 mutations cause primary ciliary dyskinesia by disruption of the outer dynein arm docking complex formation. Am J Hum Genet 2014;95:257-274.

13. Veening JG, Barendregt HP. The regulation of brain states by neuroactive substances distributed via the cerebrospinal fluid; a review. Cerebrospinal Fluid Res 2010;7:1.

14. Del Bigio MR. Ependymal cells: biology and pathology. Acta Neuropathol 2010;119:55-73

15. Karimy JK, Zhang J, Kurland DB, et al. Inflammation-dependent cerebrospinal fluid hypersecretion by the choroid plexus epithelium in posthemorrhagic hydrocephalus. Nat Med 2017;23:997.

16. Banizs B, Pike MM, Millican CL, et al. Dysfunctional cilia lead to altered ependyma and choroid plexus function, and result in the formation of hydrocephalus. Development 2005;132:5329-5339.

17. Narita K, Kawate T, Kakinuma N, Takeda S, Multiple primary cilia modulate the fluid transcytosis in choroid plexus epithelium. Traffic 2010;11:287-301.

18. Narita K, Takeda S. Cilia in the choroid plexus: their roles in hydrocephalus and beyond. Front Cell Neurosci 2015;9:39.

19. Liu B, Chen S, Johnson C, Helms JA. A ciliopathy with hydrocephalus, isolated craniosynostosis, hypertelorism, and clefting caused by deletion of Kif3a. Reprod Toxicol 2014;48:88-97.

20. Fassad MR, Patel MP, Shoemark A, et al. Clinical utility of NGS diagnosis and disease stratification in a multiethnic primary ciliary dyskinesia cohort J Med Genet 2020;57:322-330. 


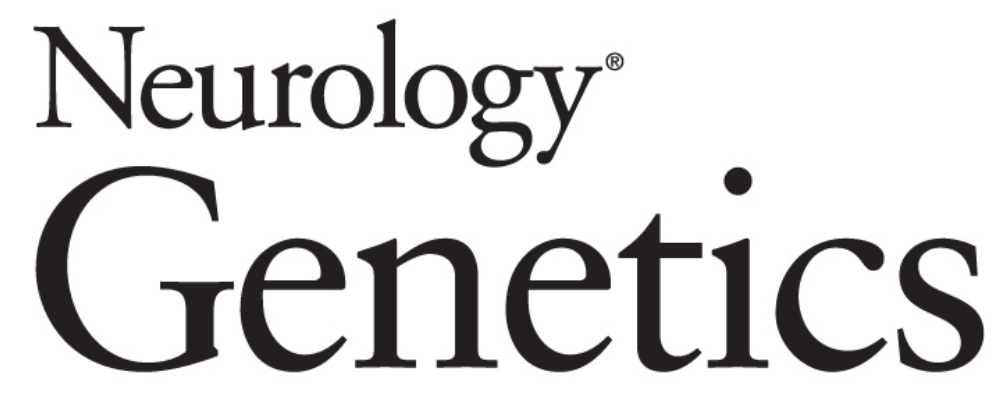

\section{Hydrocephalus and diffuse choroid plexus hyperplasia in primary ciliary dyskinesia-related MCIDAS mutation \\ Evie Alexandra Robson, Luke Dixon, Liam Causon, et al. \\ Neurol Genet 2020;6; \\ DOI 10.1212/NXG.0000000000000482}

\section{This information is current as of July 13, 2020}

\section{Updated Information \& Services}

References

Citations

Permissions \& Licensing

Reprints including high resolution figures, can be found at: http://ng.neurology.org/content/6/4/e482.full.html

This article cites 20 articles, 6 of which you can access for free at: http://ng.neurology.org/content/6/4/e482.full.html\#\#ref-list-1

This article has been cited by 1 HighWire-hosted articles: http://ng.neurology.org/content/6/4/e482.full.html\#\#otherarticles

Information about reproducing this article in parts (figures,tables) or in its entirety can be found online at:

http://ng.neurology.org/misc/about.xhtml\#permissions

Information about ordering reprints can be found online: http://ng.neurology.org/misc/addir.xhtml\#reprintsus

Neurol Genet is an official journal of the American Academy of Neurology. Published since April 2015, it is an open-access, online-only, continuous publication journal. Copyright Copyright @ 2020 The Author(s). Published by Wolters Kluwer Health, Inc. on behalf of the American Academy of Neurology.. All rights reserved. Online ISSN: 2376-7839.

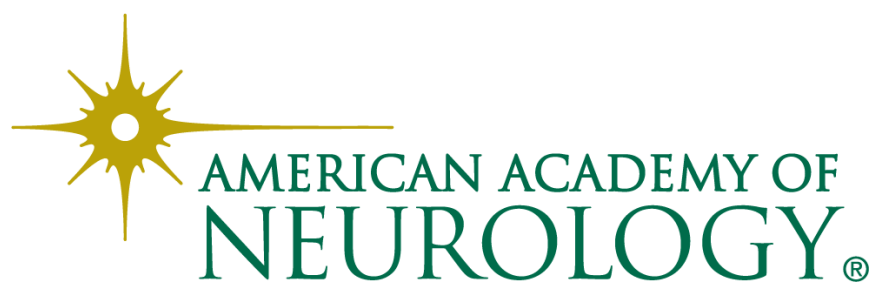

